\title{
Hydrogen and renewable energy sources integrated system for greenhouse heating
}

\author{
Ileana Blanco, Alexandros Sotirios Anifantis, Simone Pascuzzi, \\ Giacomo Scarascia Mugnozza \\ Department of Agro - Environmental Science (DISAAT), “Aldo Moro” University of Bari, (Italy)
}

\begin{abstract}
A research is under development at the Department of AgroEnvironmental Sciences of the University of Bari "Aldo Moro" in order to investigate the suitable solutions of a power system based on solar energy (photovoltaic) and hydrogen, integrated with a geothermal heat pump for powering a self sustained heated greenhouse. The electrical energy for heat pump operation is provided by a purpose-built array of solar photovoltaic modules, which supplies also a water electrolyser system controlled by embedded pc; the generated dry hydrogen gas is conserved in suitable pressured storage tank. The hydrogen is used to produce electricity in a fuel cell in order to meet the above mentioned heat pump power demand when the photovoltaic system is inactive during winter night-time or the solar radiation level is insufficient to meet the electrical demand. The present work reports some theoretical and observed data about the electrolyzer operation. Indeed the electrolyzer has required particular attention because during the experimental tests it did not show a stable operation and it was registered a performance not properly consistent with the predicted performance by means of the theoretical study.
\end{abstract}

\section{Introduction}

Advanced greenhouses mainly need heating systems, in addition to electrical energy for ventilation, irrigation and fertilization. In detail, in horticultural and floricultural context, winter heating for green-

Correspondence: Ileana Blanco, Department of Agro - Environmental Science (DISAAT), "Aldo Moro" University of Bari, via Amendola 165/A, 70126 , Bari, Italy.

Tel. /fax: +39. 0805442977 .

E-mail: ileana.blanco@uniba.it

Key words: greenhouse heating, energy savings, electrolyser, hydrogen, fuel cell, ground source heat pump.

(C) Copyright I. Blanco et al., 2013

Licensee PAGEPress, Italy

Journal of Agricultural Engineering 2013; XLIV(s2):e45

doi:10.4081/jae.2013.s2.e45

This article is distributed under the terms of the Creative Commons Attribution Noncommercial License (by-nc 3.0) which permits any noncommercial use, distribution, and reproduction in any medium, provided the original author(s) and source are credited. houses can be the $70 \%$ of production costs, being often a limit to an optimal vegetative development of protected crops for unsustainable costs (Scarascia Mugnozza G. et Anifantis A., 2009).

The use of suitable microclimate control systems, energy efficiency strategies and renewable energy sources could provide a significant impetus for greenhouse gases reduction and contribute reaching legislated energetic and environmental targets and improving the environmental performance of the greenhouses (Scarascia Mugnozza et al., 2011), ensuring at the same time optimal microclimate conditions for protected crops (Ozgener et al., 2005).

Geothermal heat pumps potentiality in the agricultural sector and especially for greenhouse heating demands have been successfully estimated (Dickson et al., 2004); in these circumstances heating plants are economically advantageous having a low environmental impact too (Benli, 2013; Chai et al., 2012; Scarascia Mugnozza et al., 2011; Ozgener, 2010; Kondili et Kaldellis, 2006; Adaro et al., 1999).

The urgent need to pass from conventional energetic systems, based on fossil fuel resources, towards energetic systems based on solar and wind energy, has to face the problems related to variable and unpredictable energy availability from renewable sources. Consequently it is necessary to provide this systems with a power back up arrangement as in example batteries, which are commonly used for this purpose but have also some limitations such as limited lifetime and low energy storage capacity. Fuel cells application, fuelled with hydrogen, is better than batteries when used to support solar energy power plants (Ro et Rahman, 1998).

Renewable sources energy can be used to generate high purity hydrogen gas through water electrolysis process; produced hydrogen, as energy vector, can serve to store energy produced in excess when compared to demand, and at a later stage it can be used as a fuel to reproduce electricity through fuel cell systems.

At present a lot of researches have been carried out and are still being developed on modelling, analysing and optimization of solar (photovoltaic and wind)-electrolyzer-fuel cell hybrid power systems with backup consisting in hydrogen storage systems (Khan et Iqbal, 2005; Jallouli et Krichen, 2012) with the hydrogen stored as liquid, as gas under pressure or through metal hydrides (Miland et Ulleberg, 2012); such researches sustain feasibility and reliability of solar hydrogen power systems.

However few studies have been done regarding the integration of solar hydrogen power systems with greenhouses, supporting that these systems provide a viable option for powering stand-alone greenhouse in a self-sustained manner (Ganguly et al., 2010).

Therefore a research is under development at the Department of Agro-Environmental Sciences of the University of Bari "Aldo Moro" in order to investigate the suitable solutions of a power system based on solar energy (photovoltaic) and hydrogen, integrated with a geothermal heat pump for powering a self sustained heated greenhouse. The present work reports some theoretical and observed data about the electrolyzer operation. 


\section{Materials and methods}

\section{The experimental greenhouse}

The experimental study was carried out at the experimental farm University of Bari sited in Valenzano (Bari, Southern Italy), latitude $41^{\circ} \mathrm{N}$. A greenhouse-integrated system composed of photovoltaic panels, electrolyser bank, Polymer Electrolyte Membrane fuel cell stacks and a geothermal heat pump was set up.

A system of equipments have been designed and installed in order to produce electricity from solar photovoltaic source (PV) and hydrogen gas from water by means of an electrolyser powered by PV. The produced hydrogen is stored in a pressure tank and than it is used as fuel by a fuel cell system producing electricity for greenhouse energy demands when photovoltaic is inactive (during night time or overcast sky).

The electrical energy produced was used for powering the heating system set in order to satisfy the thermal energy demand of $48 \mathrm{~m}^{2}$ double plastic skin greenhouse; therefore the use of renewable energy was combined with passive techniques of energy saving using an inflated double film for increasing thermal transmittance.

The main structure of the greenhouse, arched roof one, is made of tubular galvanized steel. The coverage is made of a double ethylene vinyl acetate film (multiEVA $33 \mathrm{AD} \mathrm{AF}$ ), each one having a thickness of $200 \mathrm{~m}$, with an interposed $2 \mathrm{~cm}$ air space, which is kept under constant pressure by an air pump. The base and the warheads (east and westfacing greenhouse surface) are corrugated sheets made of polyester reinforced with glass fibers (PRFV). Each greenhouse is provided with a sliding door, a vertical fan/air extractor and an air inlet louver, all of which are placed on a single warhead.

Another greenhouse unheated, with the same geometric and constructive characteristics, has been realized for comparison (Figure 1).

The two greenhouses are east-west oriented, being $8 \mathrm{~m}$ in length and $6 \mathrm{~m}$ in width, $3.5 \mathrm{~m}$ in height. Therefore the surface coverage is about $120 \mathrm{~m}^{2}$ and the volume is about $150 \mathrm{~m}^{3}$.

The distance between the two greenhouses is $12 \mathrm{~m}$; therefore there is no mutual shading.

The necessary heating power $Q_{H}$ was evaluated using the heat balance with the main power losses between the air inside the greenhouse and the external ambient. Thus $Q_{\mathrm{H}}$ was calculated by means of the following equation (1):

$$
Q_{H}=Q_{c}+Q_{v}+Q_{i}
$$

where:

$Q_{c}$ is the conduction and convection power loss through the greenhouse covering system [W];

$Q_{v}$ is the inside air leakage power loss between the internal and external ambient [W];

$Q_{i}$ is the power loss by radiation from covering film to blue sky [W].

The greenhouse heating system was realized through black plastic hose supplied by a $7.2 \mathrm{~kW}$ low-enthalpy geothermal heat pump equipped with $120 \mathrm{~m}$ vertical double U-bend ground heat exchangers.

\section{The hybrid system}

The power plant has been designed with the purpose of using the photovoltaic production also directly, avoiding the double energy conversion involving energy losses (electricity hydrogen electricity) when there is simultaneity between photovoltaic energy production and greenhouse energy demands. The designed passive loads are seasonally dependent.

The system (Figure 2) can be powered through the national electric grid in order to guarantee always the energy supply in case of default of the power system.

The whole energy system, except for PV modules and storage tanks, is enclosed in a steel cabinet (Figure 3) subdivided into two separate chambers, one encloses the process unit, the second one encloses the power supply unit. The process unit contains all equipment, piping and field instruments necessary for carrying out the water electrolysis process, and also the fuel cells.

The array of photovoltaic panels consists of 24 modules of $240 \mathrm{~W}$ peak power, maximum operating voltage $29.64 \mathrm{~V}$. Modules were grouped in two series, grouped in parallel, in order to achieve a nominal voltage of the array of $360 \mathrm{~V}$. The PV modules have a total area around $39 \mathrm{~m}^{2}$, south-oriented with an elevation angle of $30^{\circ}$ in order to maximize annual energy production (Figure 4). The PV modules have been set up on a tubular galvanized steel structure.

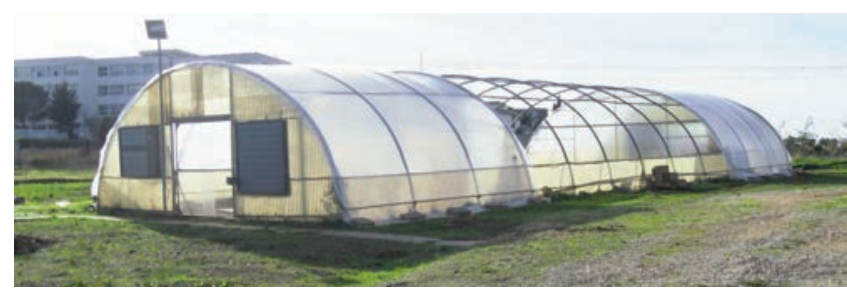

Figure 1. Experimental greenhouses.

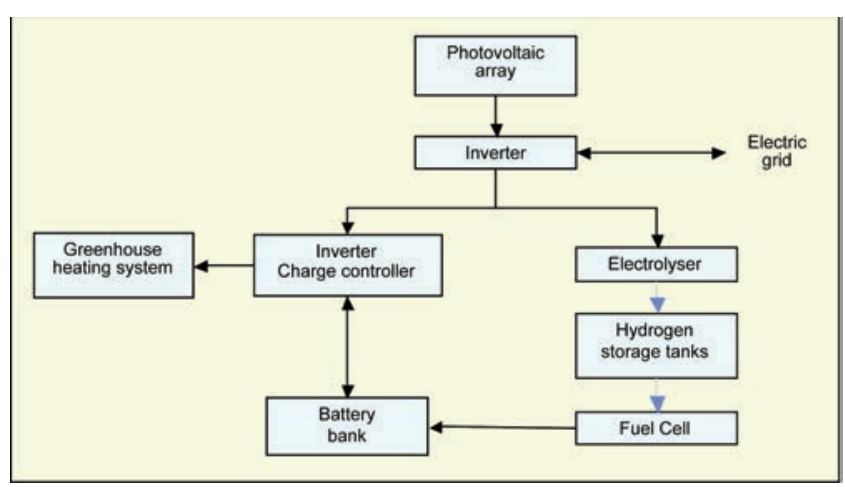

Figure 2. Functional diagram of the power plant.

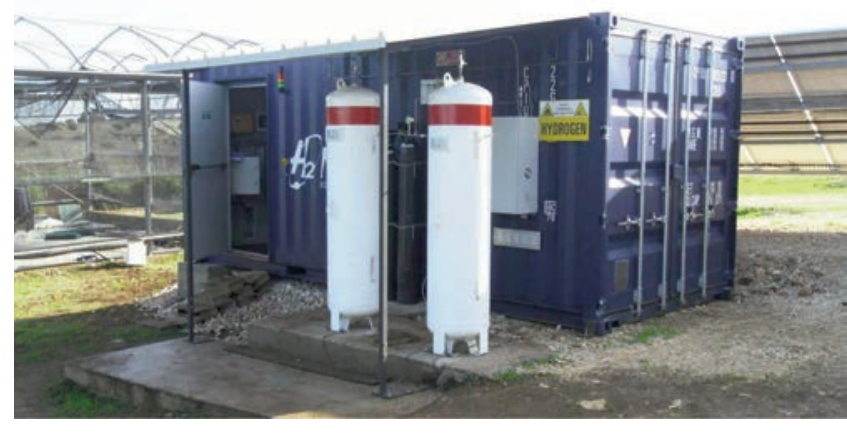

Figure 3. Plant external layout. 
The renewable energy produced by the aforesaid PV modules was converted to $\mathrm{AC}$ power by an inverter in order to feed the water electrolyser sited in the cabinet. Furthermore the AC power could also feed the grid. The inverter has an input voltage of 300-600 VDC and an output AC voltage of $230 \mathrm{VAC}$.

The electrolyser unit has an input voltage of $230 \mathrm{VAC}$ and its consumption is of $3.55 \mathrm{~kW}$. The hydrogen nominal production rate (dry gas) is $0.4 \mathrm{Nm}^{3} / \mathrm{h}$ with output pressure of $3 \mathrm{MPa}$. Moreover the hydrogen production rate is directly proportional to the AC flow set to be conducted along the cell stack. It has been chosen to add Potassium Hydroxide (KOH 28\%) to the contained water for forming the electrolyte, in order to make it highly conductive.

The produced hydrogen is stored under pressure at $3 \mathrm{MPa}$ in two steel tanks of $0.6 \mathrm{~m}^{3}$ placed outside the cabinet (Figure 3 ). The fuel cell system is based on the proton exchange membrane (PEM) technology and is set in the process unit of the cabinet; it is designed with modular cartridge technology, having a peak power of $2 \mathrm{~kW}$.

The fuel cell requires industrial grade hydrogen (99.95\%) and oxygen (air) and has as by-products pure water/vapor and heat; the output voltage is of $48 \mathrm{VDC}$ and the consumption is of 30 standard liter per minute (slpm) at $2 \mathrm{~kW}$ (operation temperatures $0^{\circ} \mathrm{C} \div 46{ }^{\circ} \mathrm{C}$ ).

The energy produced by the fuel cells is used to charge a battery bank consisting of six $12 \mathrm{~V}$ cells connected in series and in parallel providing a global energy of $900 \mathrm{Ah}$.

Finally an inverter is connected to the battery terminals in order to be used as a stand-alone sinusoidal AC voltage provider.

The system monitoring and control, placed in the control unit, is based on a programmable logic controller (PLC) and is integrated with a power supply unit. The PLC manages all the processes and safety.

This system has been set up and it has been finished in April 2013. During the month of May 2013 operation tests have been carried out paying attention on the functionality of the electrolyzer; the amount of hydrogen produced was evaluated during daytime hours of different days.

\section{Theoretical considerations concerning the electrolyzer}

According to Faraday's law, the production rate of hydrogen $M_{\text {elec }}$ in a water electrolyzer, consisting of a certain number of electrolyzer cells connected in series, can be calculated by (Li et al., 2009):

$$
M_{\text {elec }}=\eta_{F} \times N_{\text {elec }} \times I_{\text {elec }} /(n \times F) \quad\left[\mathrm{mol} \mathrm{s}^{-1}\right]
$$

where:

$\eta_{F}$ is the Faraday efficiency;

$N_{\text {elec }}$ is the number of electrolyzer cells in series;

$I_{\text {elec } i} \mathrm{~s}$ the current through the electrolyzer [A];

$n$ is the number of moles of electrons per mole of water, $n=2$;

$F \quad$ is the Faraday constant $\left(96487 \mathrm{C} \mathrm{mol}^{-1}\right)$.

The Faraday efficiency, that is often called the "current efficiency", is defined as the ratio between the actual and the theoretical maximum amount of hydrogen produced in the electrolyzer (Ulleberg, 2003).

According to the manufacturer of the electrolyzer the value of ${ }_{F}$ is equal to $91 \%$.

To produce hydrogen the working voltage $U(\mathrm{~V})$ between the two electrodes must be higher than the minimum decomposition voltage $U_{t n}$ :

$$
U_{t n}=\Delta H / n F
$$

where:

$\Delta H$ is the standard enthalpy for splitting water of hydrogen [286 kJ $\mathrm{mol}^{-1}$; $n=2$.

At standard conditions $U_{t n}=1.482 \mathrm{~V}$ (Ulleberg, 1998).

The voltage efficiency $\eta_{V}$ is defined by:

$$
V=U_{t n} / U \quad[\%]
$$

According to the manufacturer of the electrolyzer the value of $V$ is equal to $80 \%$.

Considering the registered values of the working voltage of the experimental electrolyzer, the $\eta_{V}$ can be calculated by means of eq. 4 ; thus the actual voltage efficiency $\eta_{V}$ will be $75 \%$.

The power consumption of an electrolyzer can be expressed as (Li et al., 2009):

$$
P_{\text {elec }}=I_{\text {elec }} x U x N_{\text {elec }}
$$

Thus the hydrogen production by the electrolyzer, taking into account equation 2 , can be calculated as:

$$
M_{\text {elec }}=\eta_{F} \times P_{\text {elec }} /(U \times n \times F) \quad\left[\mathrm{mol} \mathrm{s}^{-1}\right]
$$

Considering the registered values of the hydrogen production, the power consumption and the working voltage of the experimental electrolyzer, the Faraday efficiency $\eta_{F}$ can be calculated by means of eq. 6; thus the actual voltage efficiency $\eta_{F}$ will be $87 \%$.

The electrolyzer unit has a built-in gas compressor in order to store the produced hydrogen in tanks. The power necessary to compress the gas can be calculated by (Li et al., 2009):

$$
W_{c}=m_{c} x C_{p} \times T_{1} \times\left(1 / \eta_{c}\right) \times\left[\left(P_{2} / P_{I}\right)^{(r-1) / r}-1\right]
$$

where:

$m_{c}$ is the flow rate of hydrogen through the compressor $\left[\mathrm{kg} \mathrm{s}^{-1}\right]$; $C_{p}$ is the specific heat oh hydrogen at constant pressure $(14304 \mathrm{~kJ}(\mathrm{~kg}$ $\mathrm{K})^{-1}$ );

$T_{I}$ is the inlet gas temperature of the hydrogen compressor $(313.15 \mathrm{~K})$; $\eta_{c}$ is the isentropic efficiency of the compressor [\%];

$P_{2}$ is the output gas pressure of the hydrogen compressor ( $3 \mathrm{MPa}$ );

$P_{l}$ is the inlet gas pressure of the hydrogen compressor (0.6 MPa);

$r$ is the isentropic exponent of hydrogen (1.4).

The mole mass of hydrogen is $2.016\left(\mathrm{~g} \mathrm{~mol}^{-1}\right)$; therefore $m_{c}=M_{\text {elec }} x$ $2.016 / 1000\left(\mathrm{~kg} \mathrm{~s}^{-1}\right)$. The value of $\eta_{c}$ in this work is assumed equal to $68 \%$ according to manufacture data.

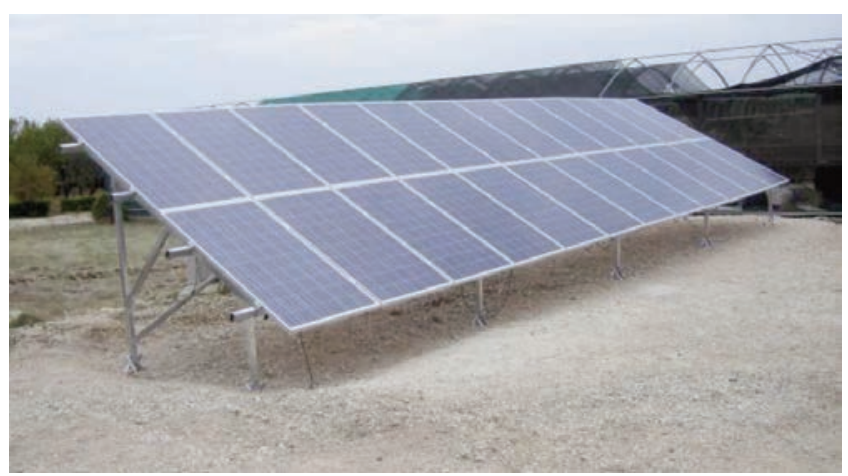

Figure 4. The photovoltaic array. 


\section{Results and discussion}

Figure 5 shows the photovoltaic electrical production $(\mathrm{kW})$ as a function of the hour during a day of May 2013; this day was characterized by a highly variable weather similarly to the other days of the month and then the evaluated day can be considered representative for May 2013. The electrolyzer started to produce hydrogen when the photovoltaic production was greater than $1.6 \mathrm{~kW}$, that is in the periods $8-10$ and 11-14. Figure 6 shows through a dashed line the amount of produced hydrogen as a function of the stack power consumption. These experimental data are compared, in the same Figure, with data (through a continuous line) calculated by means of equation 6 .

According to the experimental data a $\eta$ nd by means of theoretical considerations (Figure 6), we have assessed the actual voltage efficiency $\left(\eta_{V}=75 \%\right)$ and the actual Faraday efficiency $\left(\eta_{F}=87 \%\right)$ which are clearly lower than the manufacturer efficiency values. The actual production of hydrogen is slightly different from the calculated one obtained by means of theoretical conditions (Figure 6).

These disagreements between expected and registered values are probably due to the mathematical model. Effectively this model contemplates electrolyser working at atmospheric pressure and at constant temperature. Furthermore the compression of the hydrogen (equation 7 ) takes place after its production in suitable compressor.

The realized electrolyzer besides works under pressure of $0.3 \mathrm{MPa}$ with a changeable operative temperature $\left(20^{\circ} \mathrm{C}-80{ }^{\circ} \mathrm{C}\right)$ and the produced hydrogen is already pressed $(0.3 \mathrm{MPa})$, ready to be stored in the tanks. Consequently the power necessary to compress the hydrogen is secondary if compared to the one related to the theoretical model (equation 7)

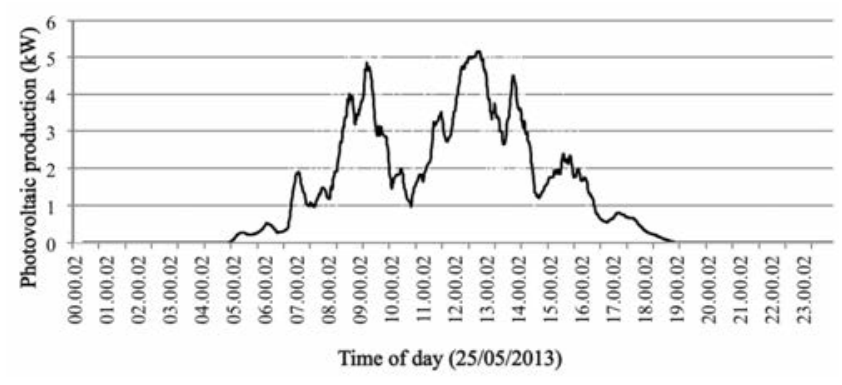

Figure 5. The daily photovoltaic production

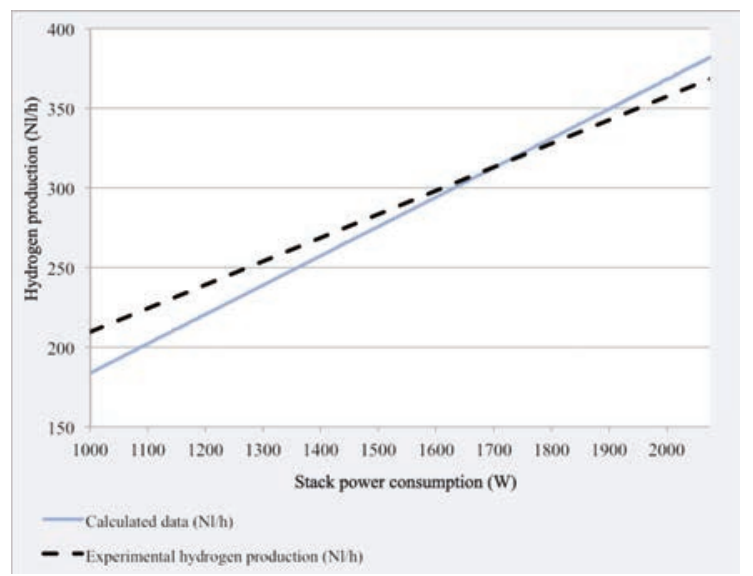

Figure 6. The hydrogen production.

\section{Conclusions}

The realized system has required the analysis of different technical characteristics related to the heating demands of the experimental greenhouse, the ground source heat pump, the hydrogen production, the storing system, the photovoltaic system. Further studies have been carried out to evaluate the connection and the affects among the members in order to obtain a hybrid system for the production and storing of green hydrogen. Above all the electrolyzer has required particular attention because during the experimental tests it did not show a stable operation and it was registered a performance not consistent with the predicted performance by means of the theoretical study. Some technical operations are being carried out for enhancing the system functionality, making it suitable to the designed task of supplying electrically the greenhouse heating system during cold periods.

\section{References}

Adaro J. A., Galimberti P. D., Lema A. I., Fasulo A., Barral J. R. 1999 Geothermal contribution to greenhouse heating. Appl. Energ. 64: 241-249.

Benli H. 2013. A performance comparison between a horizontal source and a vertical source heat pump systems for a greenhouse heating in the mild climate Elazig, Turkey", Appl. Therm. Eng. 50 (1): 197 206.

Chai L., Ma C., Ni J.Q. 2012. Performance evaluation of ground source heat pump system for greenhouse heating in norther China. Biosyst. Eng. III: 107-117.

Dickson M., Fanelli M. 2004. What is geothermal energy? Istituto di Geoscienze e Georisorse, CNR, Pisa, Italy. Available from: http://www.unionegeotermica.it/What_is_geothermal_en.html Accessed: May 2013.

Ganguly A., Misra D., Ghosh S. 2010. Modeling and analysis of solar photovoltaic-electrolyzer-fuel cell hybrid power system integrated with a floriculture greenhouse, Energ. Buildings. 42: 2036 - 2043.

Jallouli R., Krichen L. 2012. Sizing, techno-economic and generation management analysis of a stand alone photovoltaic power unit including storage devices. Energy. 40 (1): 196-209.

Khan M. J., Iqbal M. T. 2005. Pre-feasibility study of stand-alone hybrid energy systems for applications in Newfoundland. Renew. Energ. 30 (6): 835-854.

Kondili E., Kaldellis J.K. 2006. Optimal design of geothermal-solar greenhouses for the minimisation of fossil fuel consumption. Appl. Therm. Eng. 26 (8-9): 905-915.

Li C.-H., Zhu X.-J., Cao G.-Y., Sui S., Hu M.-R. 2009. Dynamic modeling and sizing optimization of stand-alone photovoltaic power systems using hybrid energy storage technology. Renew. Energ. 34 (3): 815826.

Miland H., Ulleberg Ø. 2012. Testing of a small-scale stand-alone power system based on solar energy and hydrogen. Sol. Energy. 86 (1): $666-680$.

Ozgener 0., Hepbasli A. 2005 Performance analysis of a solar assisted ground - source heat pump system for greenhouse heating: an experimental study. Build. Environ. 40: 1040-1050.

Ozgener 0.2010. Use of solar assisted geothermal heat pump and small wind turbine systems for heating agricultural and residential buildings. Energy 35: 262-268.

Ro K., Rahman S. 1998. Battery or fuel cell support for an autonomous photovoltaic power system. Renew. Energ. 13 (2): 203-213.

Scarascia Mugnozza G., Anifantis A. 2009. Dal fotovoltaico al termico. 
Colture Protette 6: 40-43

Scarascia Mugnozza G., Pascuzzi S., Anifantis A. 2011. Impianto sperimentale geotermico a bassa entalpia per riscaldamento serricolo. Prime valutazioni. Proc. Congr. Medio termine dell'Associazione italiana di Ingegneria Agraria AIIA, Belgirate, Italia. Available from: http://www.aiia.it/images/Atti/ Belgirate_2011/142.pdf Accessed: May 2013.
Ulleberg Ø. 1998. Stand-Alone Power Systems for the Future: Optimal Design, Operation \& Control of Solar-Hydrogen Energy Systems. PhD thesis, Norwegian University of Science and Technology, Trondheim.

Ulleberg $\emptyset .2003$. Modeling of advanced alkaline electrolyzers: A system simulation approach. Int. J. Hydrogen Energ. 28 (1): 21-33. 